\title{
Less Constraint of Popular Democracy, More Empowerment of Citizens
}

While I share Müller's concern about the situation in Hungary and Romania, and agree that a 'Copenhagen Commission' might be a good addition to safeguard the basic democratic values in the EU, I differ significantly in the assessment of the nature of the solution. Below, I will first discuss this difference in approach, which focuses less on constraining popular democracy and more on empowering citizens, and then offer some comments on the possible structure and power of the 'Copenhagen Commission'.

Müller's argument, as in his fascinating book, is one based on the ethics of containment - that it is necessary to contain the excesses of popular sovereignty. It is about constraining the capacity of popular democracy to be illiberal by removing agency from parliaments, and instead allocate power to other types of government, whether judicial (in the form of constitutional courts), expert based (agencies), administrative (as the EU is sometimes seen), or even the market itself. In his argument on the Hungarian situation, Müller essentially suggests yet another (external) constraint on the capacity of a 'democracy' to 'become' structurally illiberal.

In my view, this is both the wrong strategy and the wrong language to use. The ethics of containment that is not only implicit in the Union's institutional nature, but also in its legal norms, and, in a recent addition, in fiscal and budgetary policies, has a dangerous seed in its core: it limits self-determination, both on the level of the individual citizen and on the level of the polity.

We do not have to look very far for examples of this: suffice to look at the extent to which southern debtor states are subjected to stringent and harsh externally imposed policies in the most politically salient domains of all (taxation, welfare spending, pensions) without any meaningful possibility of dissenting, even when an internal democratic majority would want to.

The problem of democracy in Europe is a lack of voice. The problem in Hungary is, in fact, the same. It is a danger of a partisan constitution, which structurally silences different visions of how a 'good' society ought to look like, and instead entrenches one particular view in the institutional and normative structure of a polity. As Marco Dani has pointed out, liberal constitutions (which we, as much as Müller, want to protect), thrive on social and political conflict and contestation. Their legitimacy stems from the capacity to offer spaces of resistance for alternative voices, mediate conflicts in society, and legitimise a temporary consensus, which might be altered in the next electoral cycle.

If both the 'Hungarian' and the EU's problem, then, lie in a lack of voice and political conflict, our solution must serve to enhance both voice and political conflict within 
the political process. Rather than constraining democracy, then, what we need to focus on in order to save liberal constitutionalism is the protection of the plural nature of democracy (which entrenches procedures, not substantive norms), the empowerment of the citizen and enabling of political conflict.

I feel that this is generally a more constructive and less punitive approach to situations like the Hungarian or Romanian one, which does not isolate 'bad' Member States, but rather draw them, and their citizens and institutions, into a process of constitutional reflection. What this presupposes, of course, is mapping out the rights, structures and institutions that are, in a sense, prior to democracy, or, in other words, enable and allow for political engagement and conflict resolution. This seems to entail, at the very least and in general terms, media pluralism, an independent judiciary, and a fair political process with free and equal subjects.

This is by all means a very reduced understanding of the fundamental rights that each citizens ought to enjoy, but we are not concerned here with establishing a full range of European fundamental rights, rather with ensuring the existence of those basic structures that allow for democracy, that allow for contestation and internalises conflict, and prevent the entrenchment of a partisan constitutional logic. This may all seem very much like what the ECHR does - and it is of course partially a replication, and it will be a useful source of inspiration for the detailed understanding of the minimum requirements for a functioning democracy. The advantage of an additional structure within the EU, as will be discussed below, mainly lies in the much more politicised nature of the EU as opposed to the ECHR, and in its capacity for coercive action.

While I might differ significantly from Müller in the assumptions that underlie his call for a 'Copenhagen Commission', I do share his enthusiasm for such a possible solution. First of all, as Müller highlights, we need to think about the type of remedy that could function in the 'Hungarian scenario'. Legal solutions might be inefficient if not backed up by the coercive power that only politics (in the EU) can legitimise; while purely political solutions are sensitive to capture by the interests of the bigger Member States. Any solution, then, might require a combination of legal impartiality and political authority.

The 'Copenhagen Commission' could be a good starting point for such a procedure. It can, arguably, only function if it is very high-profile, either due to its membership (a combination of 'grand old' politicians, former ICJ, ECJ or ECHR judges, former NGO executives would allow for a good mix between stature and knowledge of the field), the day of publication of reports ( $9^{\text {th }}$ of May?), or, most probably, the significant consequences attached to its findings.

The Copenhagen Commission could use a scoreboard (the EU and Member States are used to those in the OMC and MEIP) that assesses all Member States on a yearly basis on the rights and institutions that are required to allow for a pluralist democratic process, using the 'green/orange/red' categories for impact. In case of a 'red flag' for a particular Member State in a particular area, the Copenhagen Commission would automatically (to prevent political capture) force the Commission 
to start an infringement procedure before the Court, which would not judge on the basis of the Charter of Fundamental Rights (which would entail a host of legal issues), but on the basis of a 'Copenhagen Charter' that sets out the minimum requirements for a functioning pluralist democracy in accordance with the standards currently used by the ECHR. The Court, assessing the data provided by the Copenhagen Commission and other international organisations (which it proved willing to incorporate in its decision in its N.S. judgment) would rule on the possible violation.

At the same time, a 'red flag' by the Copenhagen Commission would automatically lead to a public vote in the European Council and the EP - which, by qualified majority and absolute majority respectively, could lead to the imposition of sanctions, such as the blocking of structural, cohesion, infrastructural or CAP funds. The combination of a political and a legal remedy would add authority to a possible finding of violation, and, in cases where political leaders decide to let a fellow government off the hook, would still provide legal and normative authority to spark domestic resistance. We may also think of inserting a new (symbolic?) nuclear option of expelling Member States from the EU, after two or three consecutive 'red flags', under unanimity of the other Member States.

While, as Müller highlights, financial sanctions might hurt the weaker citizens more than the politicians, and a Court finding without political backing might be useless, I think that both (in addition to the 'orange flags' reported by the Copenhagen Commission) offer additional sites and instruments for resistance against partisan constitutionalism for citizens, political opposition parties, courts, trade unions, civil society, and NGOs, and as such might help the protection of the pluralist and liberal constitution.

In short, if we want to protect liberal constitutionalism in Europe against illiberal forces, a possible Copenhagen Commission might be a good starting point, as long as its structure is not aimed at de-politicising such issues, but rather at re-politicising them. It is not about sanctioning the governing parties of the 'bad' Member States by restricting access to their EP parties or their votes in the Council, but rather by empowering domestic and European political debate and contestation. 